\title{
KEMISKINAN DAN KETENAGAKERJAAN DI JAWA BARAT: STUDI KASUS KABUPATEN PURWAKARTA
}

\author{
Bayu Rhamadani Wicaksono ${ }^{1}$ \\ Bayu Kharisma ${ }^{2}$
}

\author{
Fakultas Ekonomi dan Bisnis Universitas Padjadjaran, Jawa Barat, Indonesia ${ }^{1,2}$ \\ Email: bayu18007@mail.unpad.ac.id
}

\begin{abstract}
The problem of poverty is a complex and multidimensional problem which covers various aspects in the human life, not least for local governments in the scope of West Java. The efforts to alleviate poverty must pay attention to the root problem of poverty itself. One of the strategic issues in the Regional Medium-Term Development Plan/ Rencana Pembangunan Jangka Menengah Daerah (RPJMD) 2018-2023 is poverty and employment. The purpose of this study is to analyze the relationship of poverty and employment in West Java in 2017-2018 with a case study in Purwakarta Regency. The data used are secondary data from district/municipality in West Java in the 20142017 period using panel data regression analysis with the Random Effects Model (REM) and the results are as follows. First, the Open Unemployment Rate/ Tingkat Pengangguran Terbuka (TPT) has a positive but not significant impact on poverty levels. Second, the number of workers in wholesale, retail, restaurant and hotel sectors has a negative and significant impact on poverty levels. Third, the number of casual workers in agricultural sector has a positive and significant impact on poverty levels.
\end{abstract}

Keywords: unemployment rate; worker in wholesale trade; retail trade; restaurants and hotels sector; casual worker in agriculture; poverty rate.

\begin{abstract}
ABSTRAK
Masalah kemiskinan merupakan masalah yang kompleks dan multidimensi yang meliputi berbagai aspek dalam lini kehidupan manusia, tak terkecuali bagi pemerintah daerah di ruang lingkup Jawa Barat. Usaha untuk mengentaskan kemiskinan harus memperhatikan akar permasalahan kemiskinan itu sendiri. Salah satu isu strategis dalam Rencana Pembangunan Jangka Menengah Daerah (RPJMD) 2018-2023 adalah penanggulangan kemiskinan dan pengangguran (ketenagakerjaan). Tujuan penelitian ini adalah menganalisis hubungan kemiskinan dan ketenagakerjaan di Jawa Barat tahun 2017-2018 dengan studi kasus Kabupaten Purwakarta. Data yang digunakan adalah data sekunder kabupaten/kota di Jawa Barat periode 2014-2017 dengan menggunakan analisis regresi data panel Random Effects Model (REM) dan hasilnya sebagai berikut. Pertama, Tingkat Pengangguran Terbuka (TPT) berpengaruh positif dan tidak signifikan terhadap tingkat kemiskinan. Kedua, jumlah pekerja di sektor perdagangan besar, eceran, rumah makan, dan hotel berpengaruh negatif dan signifikan terhadap tingkat kemiskinan. Ketiga, jumlah pekerja bebas di sektor pertanian berpengaruh positif dan signifikan terhadap tingkat kemiskinan.
\end{abstract}

Kata Kunci: Tingkat Pengangguran Terbuka (TPT); pekerja di sektor perdagangan besar; eceran; rumah makan; dan hotel; pekerja bebas di sektor pertanian; kemiskinan. 


\section{PENDAHULUAN}

Masalah kemiskinan merupakan masalah yang kompleks sehingga menjadi prioritas pembangunan, tak terkecuali bagi pemerintah daerah di ruang lingkup Jawa Barat. Pemerintah mempunyai perhatian besar dalam rangka mewujudkan masyarakat yang adil dan makmur sebagaimana termuat dalam alinea keempat Pembukaan Undang-Undang Dasar 1945. Program-program pembangunan yang telah dilaksanakan juga selalu menitikberatkan pada upaya pengentasan kemiskinan karena pada dasarnya pembangunan yang dilakukan bertujuan untuk meningkatkan kesejahteraan masyarakat. Berdasarkan hasil Susenas Maret 2018, jumlah penduduk miskin di Jawa Barat sebanyak 3.615,79 ribu jiwa atau 7,45 persen dari jumlah penduduk Jawa Barat seperti terlihat pada

Grafik 1. Selama kurun waktu 2013-2018, jumlah dan persentase penduduk miskin di Jawa Barat menunjukkan kecenderungan menurun setiap tahunnya kecuali pada tahun 2015 (BPS Provinsi Jawa Barat, 2018).

\section{Grafik 1.}

Perkembangan Jumlah dan Persentase Penduduk Miskin

Maret 2012-Maret 2018

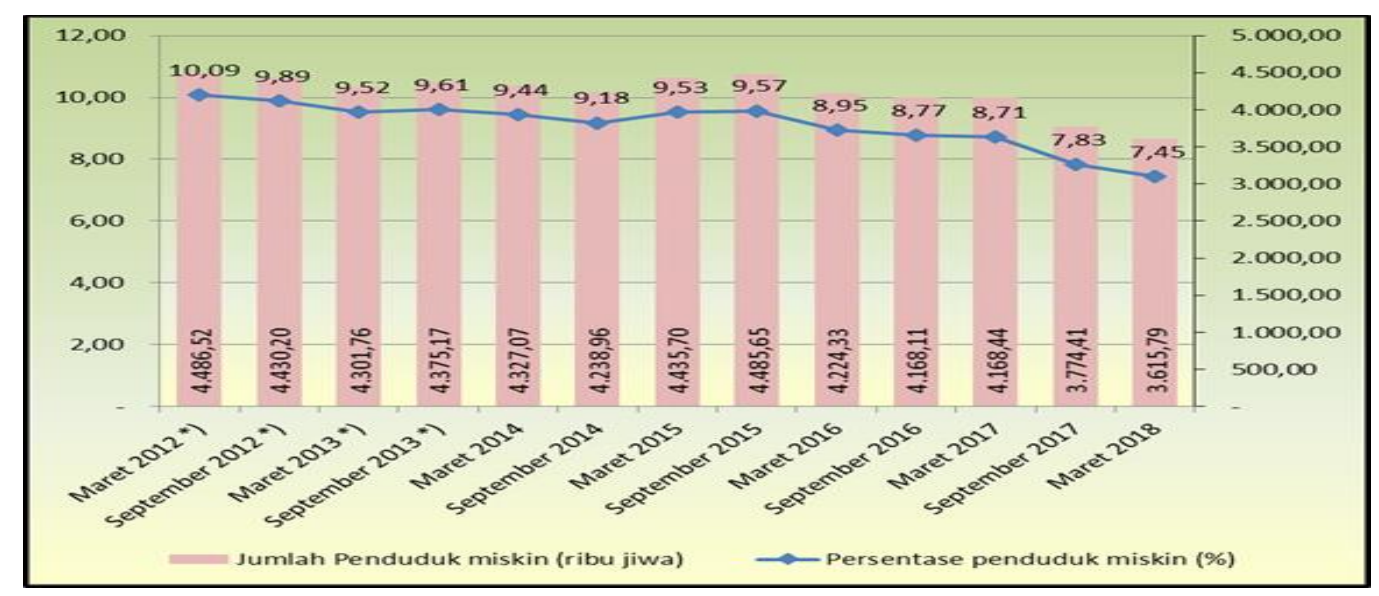

Sumber: BPS Provinsi Jawa Barat (2018) 
Masalah kemiskinan juga merupakan masalah multidimensi yang meliputi berbagai aspek dalam lini kehidupan manusia. Hal ini terjadi karena keterbatasan kemampuan manusia dalam pemenuhan kebutuhan hidupnya, seperti sandang, pangan, papan, kesehatan, pendidikan, maupun pekerjaan. Kemiskinan muncul akibat adanya gap antara ketersediaan sumber daya utama dengan kemampuan individu atau rumah tangga untuk memenuhi kebutuhan dasar (Fahar, 2015).

Usaha untuk mengentaskan kemiskinan harus memperhatikan akar permasalahan kemiskinan itu sendiri, salah satunya terkait ketenagakerjaan. Salah satu permasalahan pokok yang menjadi akar permasalahan kemiskinan adalah rendahnya pendapatan penduduk miskin karena tidak adanya pekerjaan ataupun memiliki pekerjaan tetapi upah/pendapatan rendah (Fahar, 2015). Salah satu isu strategis dalam Rencana Pembangunan Jangka Menengah Daerah (RPJMD) Kabupaten Purwakarta 2018-2023 adalah penanggulangan kemiskinan dan pengangguran (ketenagakerjaan).

Keadaan ketenagakerjaan di Provinsi Jawa Barat umumnya dan Kabupaten Purwakarta pada khususnya dapat diamati dari dua aspek, yaitu aspek ketersediaan (supply) dan aspek kebutuhan/permintaan (demand). Idealnya kedua aspek tersebut berada pada posisi yang seimbang, yang berarti bahwa jumlah penduduk yang mencari pekerjaan terpenuhi oleh jumlah lapangan kerja yang tersedia. Lapangan kerja yang paling banyak menyerap tenaga kerja, baik di Provinsi Jawa Barat maupun Kabupaten Purwakarta adalah sektor perdagangan besar, eceran, rumah makan, dan hotel dengan jumlah masing-masing 5,92 juta dan 115,2 ribu pekerja (Badan Pusat Statistik Provinsi Jawa Barat, 2018d). 
Apabila kondisi normal yang diharapkan tersebut belum terpenuhi, maka akan menyebabkan adanya pengangguran. Pada tahun 2018, Tingkat Pengangguran Terbuka (TPT) di Jawa Barat sebesar 8,17 persen dan bahkan di Kabupaten Purwakarta sebesar 9,89 persen. Angka ini jauh melebihi TPT tingkat nasional yang berada di besaran 5,34 persen (Badan Pusat Statistik Provinsi Jawa Barat, 2018d).

Beberapa permasalahan ketenagakerjaan masih kerap ditemui di Kabupaten Purwakarta. Permasalahan-permasalahan tersebut seperti yang tertuang dalam RPJMD 2018-2023, antara lain: (1) rendahnya kesempatan dan lapangan kerja; (2) rendahnya kualitas dan produktivitas tenaga kerja; (3) tingginya pengangguran terbuka; dan (4) masih kurangnya sosialisasi peraturan perlindungan tenaga kerja (Pemerintah Kabupaten Purwakarta, 2019).

Oleh karena itu, untuk menghasilkan strategi dan kebijakan yang tepat sasaran, perlu dipahami keterkaitan antara kemiskinan dan ketenagakerjaan di Jawa Barat pada umumnya dan Kabupaten Purwakarta pada khususnya. Kebijakan yang dapat mendukung pencapaian visi pembangunan jangka menengah Provinsi Jawa Barat tahun 2018-2023, yaitu "Terwujudnya Jawa Barat Juara Lahir Batin dengan Inovasi dan Kolaborasi" dan visi pembangunan jangka menengah Kabupaten Purwakarta tahun 2018-2023, yaitu "Mewujudkan Purwakarta Istimewa" (Pemerintah Kabupaten Purwakarta, 2019).

Penelitian ini bertujuan menganalisis hubungan kemiskinan dan ketenagakerjaan di Jawa Barat tahun 2017-2018 (studi kasus Kabupaten Purwakarta). Variabel ketenagakerjaan yang akan diteliti adalah Tingkat Pengangguran Terbuka (TPT), jumlah pekerja di sektor perdagangan besar, eceran, 
rumah makan, dan hotel, dan jumlah pekerja bebas di sektor pertanian. Hipotesis yang akan diuji di dalam penelitian ini adalah: 1). Tingkat Pengangguran Terbuka (TPT) memiliki pengaruh positif dan signifikan terhadap tingkat kemiskinan di Jawa Barat. 2). Jumlah pekerja di sektor perdagangan besar, eceran, rumah makan, dan hotel memiliki pengaruh negatif dan signifikan terhadap tingkat kemiskinan di Jawa Barat. 3). Jumlah pekerja bebas di sektor pertanian memiliki pengaruh positif dan signifikan terhadap tingkat kemiskinan di Jawa Barat.

Hasil penelitian ini diharapkan dapat memberikan manfaat bagi banyak pihak. Pertama, bagi pemerintah dan stake holder terkait selaku pemangku kebijakan. Kedua, bagi para akademisi sebagai tambahan ilmu pengetahuan. Ketiga, bagi para peneliti sebagai referensi dalam perbaikan dan penyempurnaan penelitian selanjutnya.

\section{METODE PENELITIAN}

Variabel yang diteliti adalah Tingkat Pengangguran Terbuka (TPT), jumlah pekerja di sektor perdagangan besar, eceran, rumah makan, dan hotel, dan jumlah pekerja bebas di sektor pertanian sebagai variabel independen sedangkan persentase jumlah penduduk miskin sebagai variabel dependen. Keseluruhan data merupakan data sekunder dari Badan Pusat Statistik (BPS) yang berasal dari 27 kabupaten/kota di Provinsi Jawa Barat periode 2017-2018.

Tingkat Pengangguran Terbuka (TPT) adalah persentase jumlah pengangguran terhadap jumlah angkatan kerja. Penduduk termasuk angkatan kerja adalah penduduk usia kerja (15 tahun dan lebih) yang bekerja, punya pekerjaan 
namun sementara tidak bekerja, dan pengangguran. Pengangguran terdiri dari: (a) Mereka yang tidak mempunyai pekerjaan/usaha dan mencari pekerjaan; (b) Mereka yang tidak mempunyai pekerjaan/usaha dan mempersiapkan usaha; (c) Mereka yang tidak mencari pekerjaan/usaha dan tidak mempersiapkan usaha karena merasa tidak mungkin mendapatkan pekerjaan; dan (d) Mereka yang sudah punya pekerjaan/usaha, tetapi belum mulai bekerja (Badan Pusat Statistik, 2018a).

Lapangan usaha adalah bidang kegiatan dari pekerjaan/usaha/ perusahaan/kantor tempat seseorang bekerja. Pekerja di sektor perdagangan adalah seseorang yang bekerja pada lapangan usaha utama di sektor perdagangan besar, eceran, rumah makan, dan hotel (Badan Pusat Statistik, 2018a).

Pekerja bebas di sektor pertanian adalah seseorang yang bekerja pada orang lain/majikan/institusi yang tidak tetap (lebih dari 1 majikan dalam sebulan terakhir) di usaha pertanian, baik berupa usaha rumah tangga maupun bukan usaha rumah tangga atas dasar balas jasa dengan menerima upah atau imbalan baik berupa uang maupun barang, dan baik dengan system pembayaran harian maupun borongan. Usaha pertanian meliputi pertanian tanaman pangan, hortikultura, perkebunan, kehutanan, peternakan, perikanan dan perburuan, termasuk juga jasa pertanian (Badan Pusat Statistik, 2018a).

Menurut Badan Pusat Statistik (2019), kemiskinan merupakan ketidakmampuan individu dalam memenuhi kebutuhan dasar minimal untuk hidup layak. BPS mengeluarkan indikator untuk menghitung tingkat kemiskinan dengan menggunakan ukuran kemampuan dalam memenuhi kebutuhan dasar (basic needs approach) untuk menyatakan seseorang atau rumah tangga masuk kategori miskin 
atau tidak. Melalui pendekatan ini, kemiskinan ditentukan atas kemampuan masyarakat dalam memenuhi minimal kebutuhan dasar yang ditandai oleh Garis kemiskinan (GK). Masyarakat yang memiliki rata-rata pengeluaran per kapita per bulan di bawah GK dikategorikan sebagai penduduk miskin.

Penelitian ini menggunakan dua metode analisis, yaitu analisis deskriptif dan analisis inferensia. Analisis deskriptif adalah metode sederhana yang digunakan untuk memberikan gambaran dan deskripsi objek berdasarkan data dan informasi yang tersedia. Analisis deskriptif disajikan dalam bentuk grafik menggunakan bantuan software Microsoft Excel 2013.

Analisis inferensia digunakan untuk mengetahui pengaruh Tingkat Pengangguran Terbuka (TPT), jumlah pekerja di sektor perdagangan besar, eceran, rumah makan, dan hotel, dan jumlah pekerja bebas di sektor pertanian terhadap tingkat kemiskinan di Jawa Barat periode 2017-2018. Hasil analisis akan dikomparasi dengan kondisi ketenagakerjaan dan kemiskinan di Kabupaten Purwakarta. Analisis yang digunakan adalah analisis regresi data panel dan pengolahan data dengan bantuan software EViews 10. Model regresi yang digunakan adalah sebagai berikut.

$$
Y_{i t}=\alpha+\beta_{1} X 1_{i t}+\beta_{2} X 2_{i t}+\beta_{3} X 3_{i t}+\varepsilon_{i t}
$$

Keterangan:

$\mathrm{Y} \quad$ : persentase jumlah penduduk miskin

$\mathrm{X}_{1} \quad$ : persentase Tingkat Pengangguran Terbuka (TPT)

$\mathrm{X}_{2} \quad$ : jumlah pekerja di sektor perdagangan

$\mathrm{X}_{3} \quad$ : jumlah pekerja bebas di sektor pertanian

$i \quad:$ Kabupaten/kota di Provinsi Jawa Barat urutan ke- $i$

$t \quad$ : Periode penelitian (tahun 2017-2018)

$\alpha \quad$ : Intersep

$\beta \quad$ : Koefisien dari setiap variabel independen 
$\varepsilon_{i t} \quad:$ Error term

Menurut Baltagi (2005), tahapan prosedur analisis regresi data panel adalah: Spesifikasi model, dibentuk berdasarkan penelitian-penelitian sebelumnya dengan tujuan memilih variabel dependen dan variabel independen. Dalam penelitian ini, variabel dependen adalah persentase jumlah penduduk miskin dan variabel independen adalah persentase Tingkat Pengangguran Terbuka (TPT), jumlah pekerja di sektor perdagangan, dan jumlah pekerja bebas di sektor pertanian.

Identifikasi model, terdapat tiga model dalam regresi data panel, yaitu Common Effects Model (CEM), Fixed Effects Model (FEM), dan Random Effects Model (REM). Diperlukan pemilihan model terbaik dengan melakukan Uji Chow, Uji Hausman, dan Uji BP-LM.

Uji asumsi klasik, setelah mendapatkan model terbaik, langkah selanjutnya adalah melakukan uji asumsi klasik. Ada empat asumsi klasik yang harus terpenuhi, yaitu normalitas, non-multikolinieritas, homoskedastisitas, dan non-autokorelasi.

Uji signifikansi model, setelah model yang dipilih memenuhi semua uji asumsi klasik, uji signifikasi harus dilakukan. Uji signifikansi menggunakan uji-t, uji-F, dan adjusted $\mathrm{R}^{2}$.

Interpretasi model, setelah semua tahapan dilakukan, langkah terakhir adalah melakukan interpretasi atau menjelaskan model yang telah terpilih. Penjelasan didasarkan pada teori-teori yang telah diajukan dan membandingkan dengan penelitian-penelitian terkait yang terdahulu. 


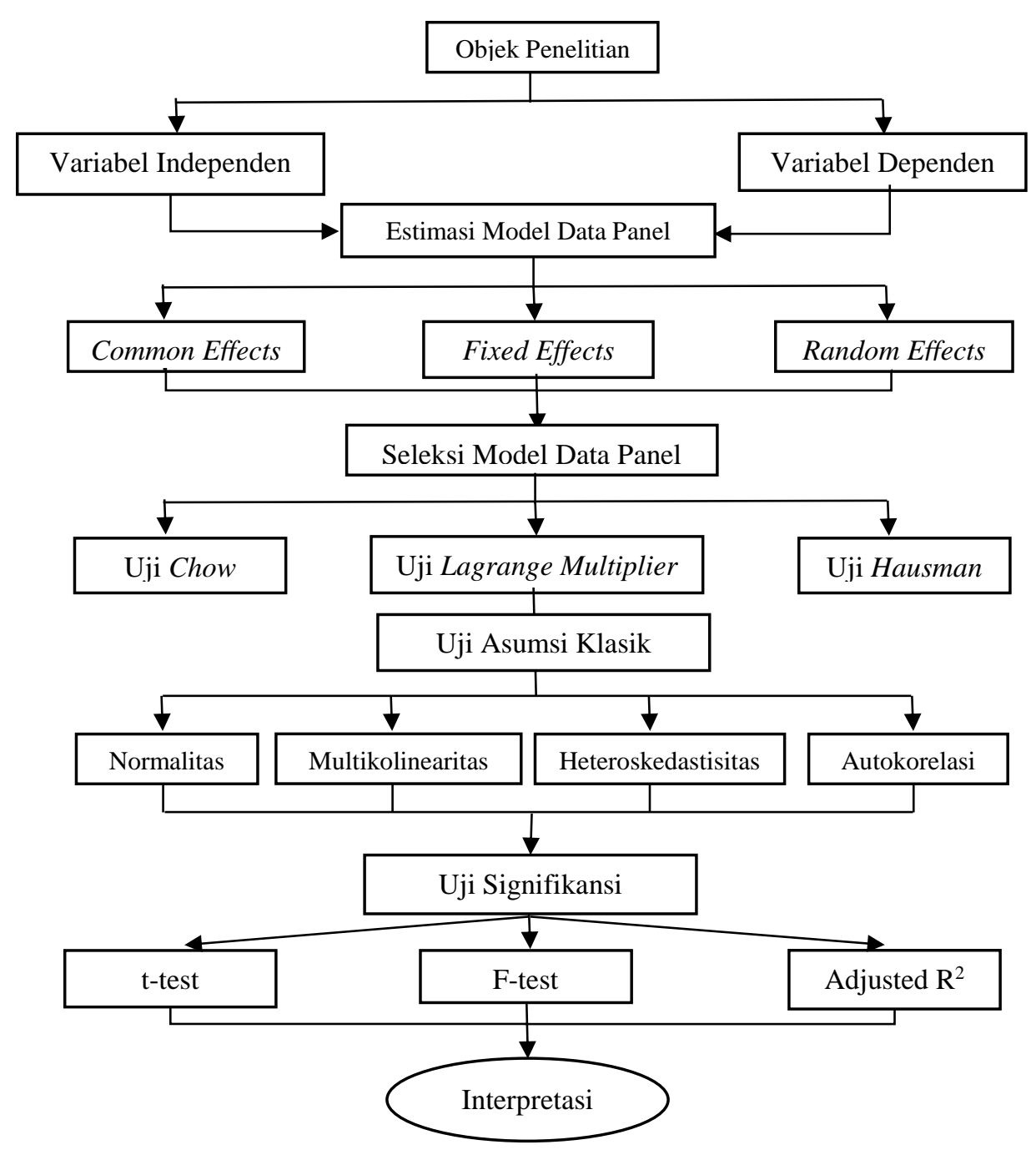

Gambar 1.

Prosedur Analisis Data Panel

\section{HASIL DAN PEMBAHASAN}

Analisis deskriptif dalam penelitian ini menggunakan bantuan grafik untuk melihat gambaran umum ketenagakerjaan di Provinsi Jawa Barat pada umumnya dan Kabupaten Purwakarta pada khususnya. Lebih jelasnya dapat dilihat pada Grafik 2. 


\section{Grafik 2.}

Tingkat Pengangguran Terbuka (TPT) Jawa Barat menurut Kabupaten/Kota Tahun 2017-2018 (Persentase)

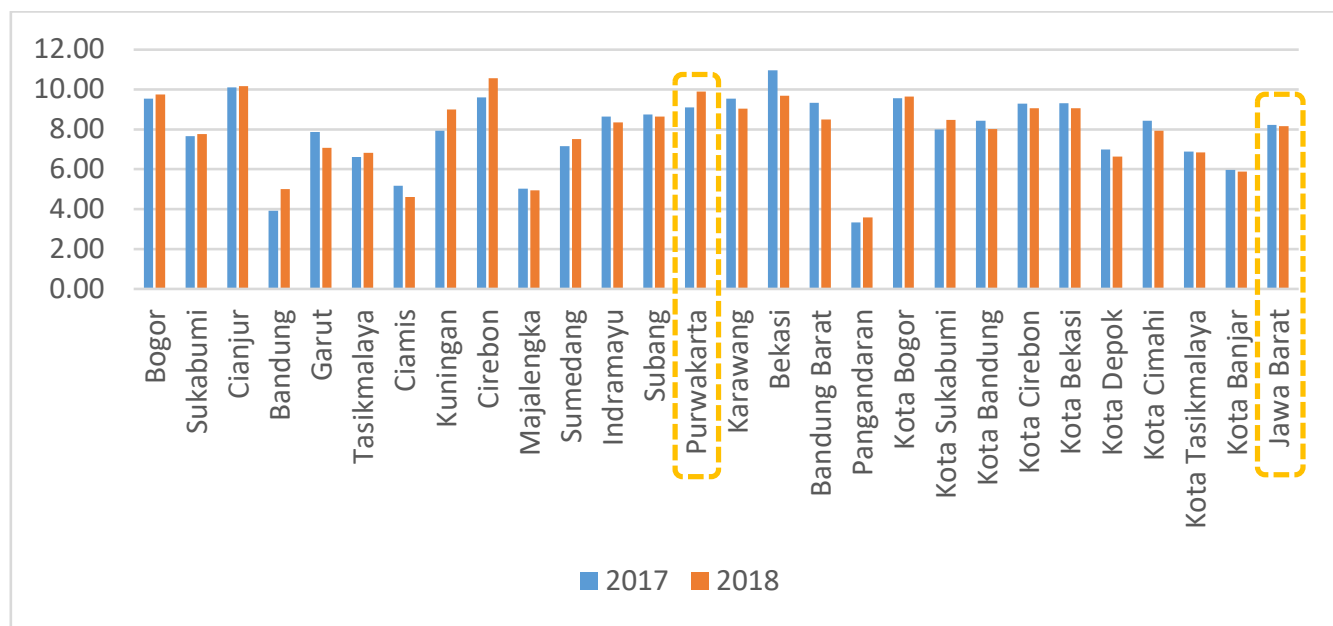

Sumber: Badan Pusat Statistik Provinsi Jawa Barat (2017 dan 2018)

Berdasarkan Grafik 2, Tingkat Pengangguran Terbuka (TPT) Jawa Barat mengalami penurunan dari 8,22 persen di tahun 2017 menjadi 8,17 persen di tahun 2018. Namun, TPT Kabupaten Purwakarta justru mengalami kenaikan dari 9,11 persen di tahun 2017 menjadi 9,89 persen di tahun 2018. Fakta ini sesuai dengan salah satu permasalahan dalam Rencana Pembangunan Jangka Menengah Daerah (RPJMD) Kabupaten Purwakarta 2018-2023, yaitu tingginya pengangguran terbuka. Kabupaten/kota lain dengan kenaikan TPT cukup tinggi seperti yang dialami Kabupaten Purwakarta adalah Kabupaten Bandung, Kabupaten Kuningan, dan Kabupaten Cirebon. Hal ini yang menjadi penyebab tingkat pengangguran di Jawa Barat pada tahun 2018 menempati posisi kedua setelah Banten (8,52 persen). 


\section{Grafik 3.}

Penduduk Jawa Barat Berumur 15 Tahun ke Atas yang Bekerja Selama Seminggu yang Lalu dengan Lapangan Pekerjaan Utama di Sektor Perdagangan Besar, Eceran, Rumah Makan, dan Hotel Menurut Kabupaten/Kota, 2017-2018

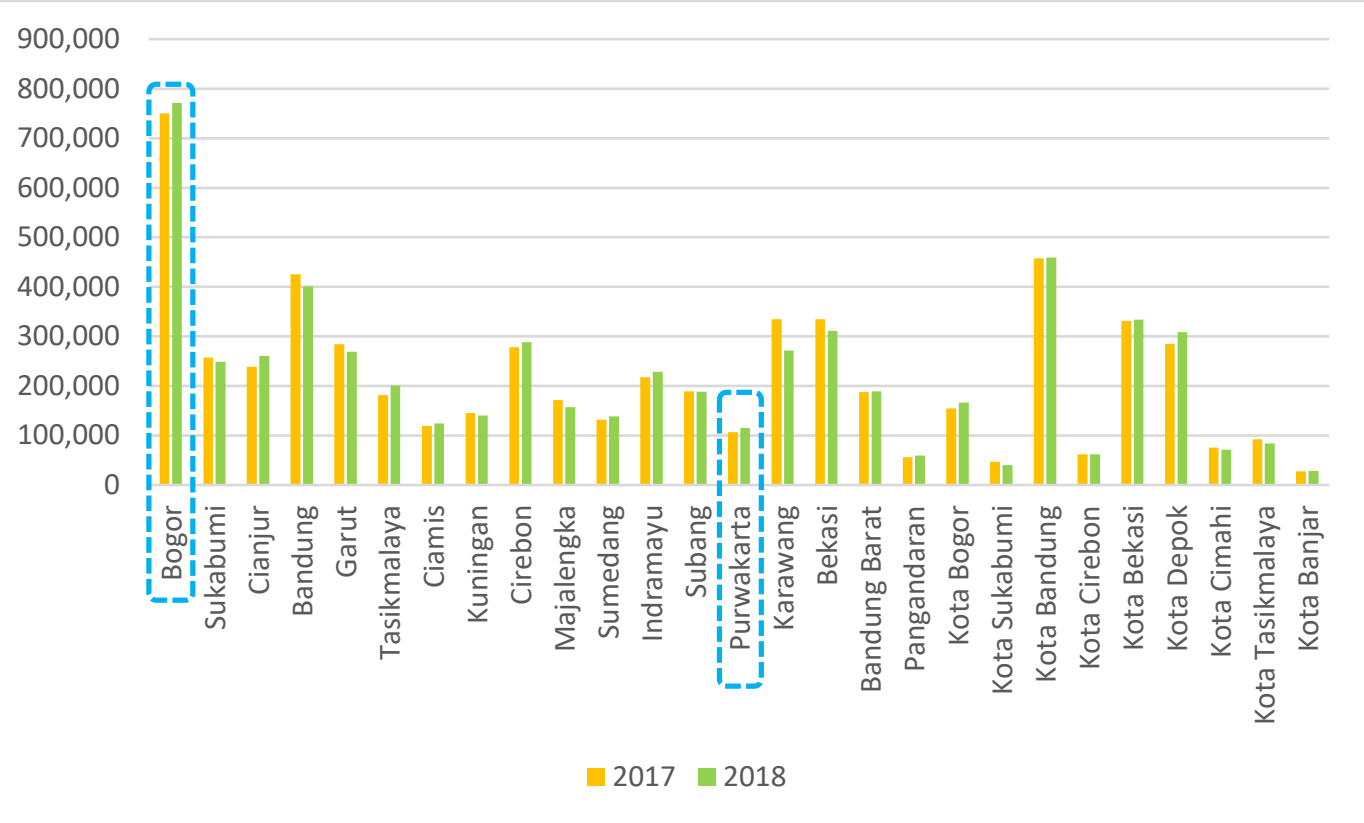

Sumber: Badan Pusat Statistik Provinsi Jawa Barat (2017 dan 2018)

Berdasarkan

\section{Grafik 3}

Grafik 3, kabupaten/kota dengan jumlah pekerja sektor perdagangan besar, eceran, rumah makan, dan hotel terbanyak adalah Kabupaten Bogor sebesar 750 
ribu di tahun 2017 dan meningkat menjadi 772 ribu di tahun 2018 atau sebesar 13 persen dari total pekerja di Jawa Barat. Sedangkan Kabupaten Purwakarta sebesar 107 ribu di tahun 2017 dan meningkat menjadi 115 ribu di tahun 2018 atau sebesar 1,9 persen dari total pekerja di Jawa Barat. Jumlah pekerja sektor perdagangan besar, eceran, rumah makan, dan hotel di Kabupaten Purwakarta memang tidak sebanyak pekerja di Kabupaten Bogor, namun kenaikan jumlah pekerja diharapkan mampu mengurangi tingkat kemiskinan di Kabupaten Purwakarta mengingat sektor ini merupakan lapangan usaha yang paling banyak menyerap tenaga kerja.

\section{Grafik 4.}

Penduduk Jawa Barat Berumur 15 Tahun ke Atas yang Bekerja Selama Seminggu yang Lalu sebagai Pekerja Bebas di Sektor Pertanian Menurut Kabupaten/Kota, 2017-2018

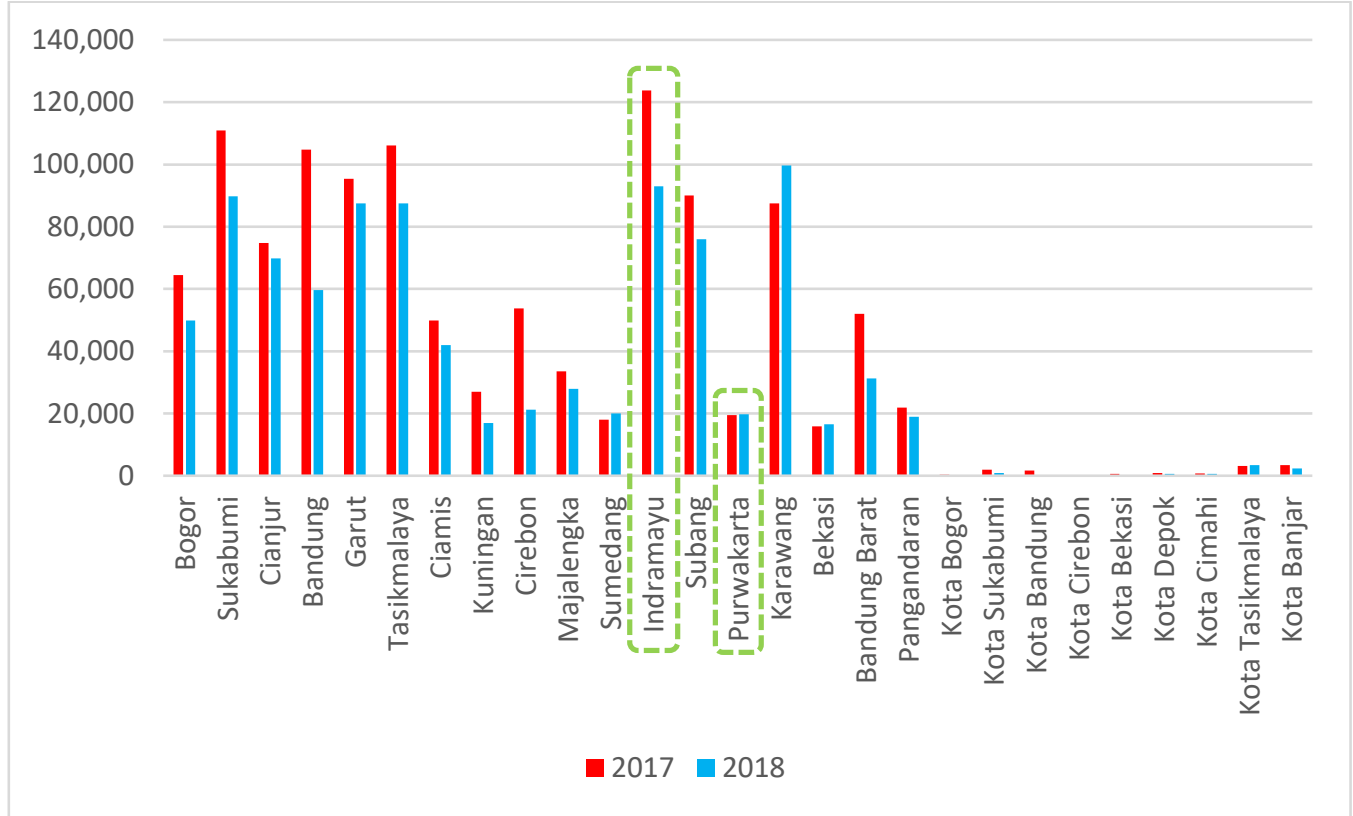

Sumber: Badan Pusat Statistik Provinsi Jawa Barat (2017 dan 2018)

Berdasarkan Grafik 4 
Grafik 3, kabupaten/kota dengan jumlah pekerja bebas di sektor pertanian terbanyak adalah Kabupaten Indramayu sebesar 124 ribu di tahun 2017 dan turun menjadi 93 ribu di tahun 2018 atau sebesar 5 persen dari total pekerja bebas sektor pertanian di Jawa Barat. Sedangkan Kabupaten Purwakarta sebesar 19 ribu di tahun 2017 dan meningkat menjadi 20 ribu di tahun 2018 atau sebesar 2 persen dari total pekerja bebas sektor pertanian di Jawa Barat. Fenomena peningkatan jumlah pekerja bebas harus dicermati dengan baik karena biasanya rata-rata upah/gaji bersih mereka masih jauh di bawah buruh/karyawan/pegawai.

Model regresi data panel digunakan untuk mengidentifikasi pengaruh pajak daerah dan retribusi daerah terhadap pertumbuhan ekonomi di Indonesia. Terdapat tiga kemungkinan model estimasi regresi data panel, yaitu Common Effects Model (CEM), Fixed Effects Model (FEM), dan Random Effects Model (REM). Untuk mengetahui model yang terbaik, maka dilakukan Uji Chow, Uji Hausman, dan Uji Breusch-Pagan Lagrange Multiplier.

Tabel 1.

Hasil Uji Chow

Redundant Fixed Effects Tests Equation: Untitled Test cross-section fixed effects

\begin{tabular}{lrrr}
\hline \hline Effects Test & Statistic & d.f. & Prob. \\
\hline \hline Cross-section F & 16.511114 & $(26,24)$ & 0.0000 \\
Cross-section Chi-square & 158.677703 & 26 & 0.0000 \\
\hline \hline
\end{tabular}

Sumber: Output EViews 10 
Uji Chow dilakukan untuk memilih model antara FEM dan CEM. Hasil Tabel 1 menunjukkan nilai probabilitas mendekati 0,0000 sedangkan nilai alpha 0,05 sehingga tolak Ho. Maka, regresi panel FEM lebih baik dibandingkan CEM.

Tabel 2.

\section{Hasil Uji Hausman}

\begin{tabular}{|c|c|c|c|}
\hline Test Summary & $\begin{array}{l}\text { Chi-Sq. } \\
\text { Statistic }\end{array}$ & Chi-Sq. d.f. & Prob. \\
\hline Cross-section random & 3.679172 & 3 & 0.2983 \\
\hline
\end{tabular}

Sumber: Output EViews 10

Uji Hausman dilakukan untuk memilih model antara REM dan FEM. Hasil Tabel 2 menunjukkan nilai probabilitas 0,2983 sedangkan nilai alpha 0,05 sehingga tidak tolak Ho. Maka, regresi panel REM lebih baik dibandingkan FEM. Dari hasil uji Chow dan uji Hausman menunjukkan bahwa REM > FEM > CEM sehingga Uji Breusch-Pagan Lagrange Multiplier tidak perlu dilakukan.

Setelah mendapatkan model REM sebagai model terbaik, maka tahapan berikutnya adalah melakukan uji asumsi klasik. Ada empat asumsi klasik yang harus terpenuhi, yaitu normalitas, non-multikolinieritas, homoskedastisitas, dan non-autokorelasi.

\section{Grafik 5.}

\section{Hasil Uji Normalitas}




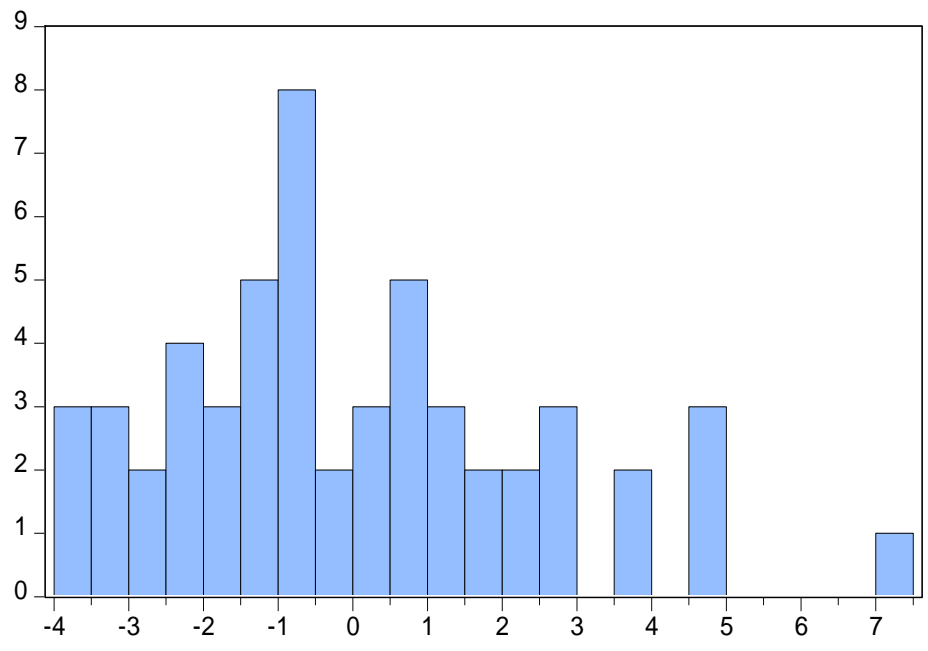

Series: Standardized Residuals Sample 20172018

Observations 54

Mean $\quad-3.45 e-16$

Median $\quad-0.630430$

Maximum 7.079147

Minimum $\quad-3.892319$

Std. Dev. $\quad 2.472543$

Skewness $\quad 0.632643$

Kurtosis $\quad 3.014732$

Jarque-Bera 3.602619

Probability $\quad 0.165083$

Sumber: Output EViews 10

Salah satu cara untuk menguji normalitas adalah dengan melihat sebaran residual dalam bentuk kurva. Berdasarkan Grafik 5 diperoleh nilai probabilitas 0,165083 sedangkan nilai alpha 0,05 sehingga tidak tolak $\mathrm{H}_{0}$. Hal ini menunjukkan bahwa residual berdistribusi normal sehingga asumsi normalitas terpenuhi.

Tabel 3.

\section{Hasil Uji Multikolinearitas}

\begin{tabular}{ccccc}
\hline Variabel & $\mathrm{X}_{1}$ & $\mathrm{X}_{2}$ & $\mathrm{X}_{3}$ & $\mathrm{Y}$ \\
\hline $\mathrm{X}_{1}$ & 1,0000 & 0,2718 & -0.0324 & $-0,0151$ \\
$\mathrm{X}_{2}$ & 0,2718 & 1,0000 & 0,2967 & $-0,2597$ \\
$\mathrm{X}_{3}$ & $-0,0324$ & 0,2967 & 1,0000 & 0,3940 \\
$\mathrm{Y}$ & $-0,0151$ & $-0,2597$ & 0,3940 & 1,0000 \\
\hline
\end{tabular}

Sumber: Output EViews 10

Dari Tabel 3 terlihat bahwa tidak adanya multikolinearitas karena koefisien korelasi antar variabel independen kurang dari 0,80. Hal ini menunjukkan bahwa dalam model regresi tidak terdapat korelasi antara sesama variabel independen. Selain itu, koefisien korelasi antara variabel independen dan variabel dependen 
kurang dari 0,80 . Hal ini menunjukkan bahwa tidak terdapat korelasi timbal balik antara variabel independen dan variabel dependen.

Uji Heteroskedastisitas, model yang terpilih adalah Random Effects Model (REM), maka pengujian heteroskedastisitas dapat dikatakan selesai. Hal ini disebabkan metode REM dengan Generalized Least Square (GLS) dapat mengatasi pelanggaran heteroskedastisitas.

Uji autokorelasi dapat dilakukan dengan cara melihat nilai Durbin-Watson. Jika nilai Durbin-Watson dekat dengan 2, maka asumsi non autokorelasi terpenuhi. Nilai Durbin-Watson sebesar 2,081863 (Tabel 4) sehingga dapat disimpulkan bahwa tidak terjadi autokorelasi.

Tabel 4.

\section{Hasil Olah Data Estimasi Random Effects Model}

Dependent Variable: $Y$

Method: Panel EGLS (Cross-section random effects)

Sample: 20172018

Periods included: 2

Cross-sections included: 27

Total panel (balanced) observations: 54

Swamy and Arora estimator of component variances

\begin{tabular}{crrrr}
\hline \hline Variable & Coefficient & Std. Error & t-Statistic & Prob. \\
\hline \hline C & 6.598794 & 1.940609 & 3.400373 & 0.0013 \\
X1 & 0.248707 & 0.236210 & 1.052907 & 0.2974 \\
X2 & $-7.95 \mathrm{E}-06$ & $3.32 \mathrm{E}-06$ & -2.395837 & 0.0204 \\
X3 & $4.57 \mathrm{E}-05$ & $1.03 \mathrm{E}-05$ & 4.421570 & 0.0001 \\
\hline \hline & Weighted Statistics & & \\
\hline \hline R-squared & \multirow{2}{*}{0.296731} & Mean dependent var & 1.996830 \\
Adjusted R-squared & 0.254534 & S.D. dependent var & 0.980146
\end{tabular}




\begin{tabular}{llll} 
S.E. of regression & 0.846262 & Sum squared resid & 35.80795 \\
F-statistic & 7.032170 & Durbin-Watson stat & 2.081863 \\
Prob(F-statistic) & 0.000491 & & \\
\hline \hline
\end{tabular}

Sumber: Output EViews 10

Berdasarkan Tabel 4 terlihat nilai probabilitas statistik uji $\mathrm{F}$ sebesar 0,000491. Hal ini menunjukkan bahwa Tingkat Pengangguran Terbuka (TPT), jumlah pekerja di sektor perdagangan besar, eceran, rumah makan, dan hotel, dan jumlah pekerja bebas di sektor pertanian secara bersama-sama signifikan memengaruhi tingkat kemiskinan di Jawa Barat pada tingkat kepercayaan 95 persen.

Selain itu, berdasarkan nilai probabilitas dari statistik uji $\mathrm{t}$ dapat disimpulkan bahwa jumlah pekerja di sektor perdagangan besar, eceran, rumah makan, dan hotel dan jumlah pekerja bebas di sektor pertanian secara parsial signifikan memengaruhi tingkat kemiskinan di Jawa Barat dengan nilai probabilitas kurang dari alpha 0,05. Hal ini menunjukkan bahwa keberartian model yang diperoleh sudah cukup baik sehingga dapat dilanjutkan ke tahap analisis dan interpretasi. Persamaan yang diperoleh adalah sebagai berikut:

$$
\mathrm{Y}_{\mathrm{it}}=6,598794+0,248707 \mathrm{X} 1_{\mathrm{it}}-7,95 \mathrm{E}-06 \mathrm{X} 2_{\mathrm{it}}+4.57 \mathrm{E}-05 \mathrm{X} 3_{\mathrm{it}}
$$

Berdasarkan hasil analisis, Tingkat Pengangguran Terbuka (TPT) berpengaruh positif dan tidak signifikan terhadap tingkat kemiskinan di Provinsi Jawa Barat. Jadi, hasil penelitian sesuai dengan hipotesis yang menyatakan bahwa semakin menurun TPT, semakin menurun tingkat kemiskinan, namun pengaruh yang diberikan tidak signifikan. Fenomena seperti ini terjadi karena turunnya pengangguran tidak melihat besaran upah yang menjadi indikator kesejahteraan di 
mana para penduduk hanya bekerja di sektor informal atau di sektor yang pendapatannya di bawah/sekitar garis kemiskinan. Hasil ini sejalan dengan riset Amalia (2012) dimana pengangguran secara parsial tidak berpengaruh signifikan terhadap kemiskinan.

Sedangkan dalam penelitian Mahsunah (2013) diperoleh hasil bahwa variabel pengangguran berpengaruh positif dan signifikan terhadap kemiskinan di Jawa Timur. Riset Febriani (2018) juga menunjukkan tingkat pengangguran memberikan pengaruh positif dan signifikan terhadap kemiskinan di Provinsi Jawa Tengah.

Hasil lainnya dari studi Fahar (2015) menunjukkan bahwa TPT mewakili ukuran kuantitas tenaga kerja yang tidak terserap dalam dunia kerja. Semakin banyak tenaga kerja yang terserap dalam dunia kerja berdampak terhadap penurunan tingkat kemiskinan di Riau.

Berdasarkan hasil analisis, jumlah pekerja di sektor perdagangan besar, eceran, rumah makan, dan hotel berpengaruh negatif dan signifikan terhadap tingkat kemiskinan di Provinsi Jawa Barat. Jadi, hasil penelitian sesuai dengan hipotesis yang menyatakan bahwa semakin meningkat jumlah pekerja di sektor perdagangan, maka semakin menurun tingkat kemiskinan. Sektor perdagangan yang menyumbang jumlah pekerja terbanyak baik di Provinsi Jawa Barat maupun Kabupaten Purwakarta terbukti dapat memberikan dampak dalam upaya menurunkan tingkat kemiskinan.

Hasil ini sejalan dengan penelitian Ansori \& Priyono (2018) dimana penyerapan tenaga kerja merupakan faktor yang krusial karena berpengaruh 
signifikan terhadap jumlah kemiskinan di Provinsi Jawa Timur. Hal ini menjadikan peningkatan penyerapan tenaga kerja sebagai prioritas utama untuk mengurangi jumlah penduduk miskin.

Berdasarkan hasil analisis, jumlah pekerja bebas di sektor pertanian berpengaruh positif dan signifikan terhadap tingkat kemiskinan di Provinsi Jawa Barat. Jadi, hasil penelitian sesuai dengan hipotesis yang menyatakan bahwa semakin menurun jumlah pekerja bebas di sektor pertanian, maka semakin menurun tingkat kemiskinan. Dalam penelitian Sudiana \& Sudiana (2015) diperoleh hasil bahwa struktur tenaga kerja pertanian secara parsial berpengaruh positif namun tidak signifikan terhadap kemiskinan di Provinsi Bali.

Mengutip Berita Resmi Statistik (BRS) dari Badan Pusat Statistik Provinsi Jawa Barat (2018a), Garis Kemiskinan (GK) Jawa Barat pada Maret 2018 sebesar Rp. 367.755,- per kapita per bulan. Jika asumsi 1 rumah tangga terdiri dari 5 orang, maka GK setiap rumah tangga adalah Rp. 1.838 .775 ,- per bulan. Berdasarkan data Badan Pusat Statistik (2018b), pekerja bebas di sektor pertanian pada Agustus 2018 memiliki rata-rata pendapatan bersih sebesar Rp. 1.103.093,- sehingga masuk kategori miskin.

\section{SIMPULAN DAN SARAN}

Berdasarkan analisis deskriptif, Tingkat Pengangguran Terbuka (TPT) Kabupaten Purwakarta mengalami kenaikan dari 9,11 persen di tahun 2017 menjadi 9,89 persen di tahun 2018. Hal ini berdampak pada tingkat pengangguran di Jawa Barat pada tahun 2018 menempati posisi kedua. Jumlah pekerja sektor perdagangan 
besar, eceran, rumah makan, dan hotel Kabupaten Purwakarta sebesar 107 ribu di tahun 2017 dan meningkat menjadi 115 ribu di tahun 2018 atau sebesar 1,9 persen dari total pekerja di Jawa Barat. Kenaikan jumlah pekerja diharapkan mampu mengurangi tingkat kemiskinan karena sektor ini paling banyak menyerap tenaga kerja. Jumlah pekerja bebas sektor pertanian di Kabupaten Purwakarta sebesar 19 ribu di tahun 2017 dan meningkat menjadi 20 ribu di tahun 2018 atau sebesar 2 persen dari total pekerja di Jawa Barat. Fenomena peningkatan jumlah pekerja bebas harus dicermati dengan baik karena biasanya rata-rata upah/gaji bersih mereka masih jauh di bawah buruh/karyawan/pegawai.

Tujuan utama penelitian ini adalah menganalisis hubungan kemiskinan dan ketenagakerjaan di Jawa Barat tahun 2017-2018 dengan studi kasus Kabupaten Purwakarta. Berdasarkan analisis inferensia menggunakan regresi data panel Random Effects Model (REM), hasil penelitian menunjukkan hasil seperti berikut. Pertama, Tingkat Pengangguran Terbuka (TPT) berpengaruh positif dan tidak signifikan terhadap tingkat kemiskinan. Kedua, jumlah pekerja di sektor perdagangan besar, eceran, rumah makan, dan hotel berpengaruh negatif dan signifikan terhadap tingkat kemiskinan. Ketiga, jumlah pekerja bebas di sektor pertanian berpengaruh positif dan signifikan terhadap tingkat kemiskinan.

Berdasarkan hasil penelitian, disampaikan beberapa saran yang diharapkan menjadi bahan pertimbangan bagi pemerintah. Pertama, Pemerintah Kabupaten Purwakarta melakukan evaluasi upah pekerja di sektor yang pendapatannya di bawah/sekitar garis kemiskinan sehingga dapat menetapkan kebijakan yang berdampak pada peningkatan kesejahteraan dan taraf hidup layak para pekerja. 
Kedua, pemerintah membuka lapangan pekerjaan yang sangat diperlukan dan banyak menyerap banyak tenaga kerja, seperti lapangan usaha di sektor perdagangan besar, eceran, rumah makan, dan hotel, sehingga mampu menurunkan angka kemiskinan yang ada di Kabupaten Purwakarta. Ketiga, Pemerintah Kabupaten Purwakarta memberikan penyuluhan dan bantuan usaha agar dapat mengarahkan para pekerja bebas di sektor pertanian alih pekerjaan ke sektor formal atau bahkan berusaha sendiri.

\section{REFERENSI}

Amalia, F. (2012). Pengaruh Pendidikan, Pengangguran dan Inflasi Terhadap Tingkat Kemiskinan di Kawasan Timur Indonesia (KTI) Periode 2001-2010. Jurnal Ilmiah Econosains, $\quad X(2), \quad 158-169$. https://doi.org/https://doi.org/10.21009/econosains.0102.02

Ansori, \& Priyono, J. (2018). Analisis Pengaruh Penyerapan Tenaga Kerja dan Upah Minimum Pekerja terhadap Kemiskinan di Provinsi Jawa Timur Tahun 2009-2015. Jurnal Ekonomi \& Bisnis, 3(1), 555-572. Retrieved from http://jurnal.untag-sby.ac.id/index.php/JEB17/article/view/1344

Badan Pusat Statistik. (2018a). Keadaan Angkatan Kerja di Indonesia, Agustus 2018. (S. S. Ketenagakerjaan, Ed.). Jakarta: Badan Pusat Statistik.

Badan Pusat Statistik. (2018b). Keadaan Pekerja di Indonesia, Agustus 2018. (Subdirektorat Statistik Upah dan Pendapatan, Ed.). Jakarta: Badan Pusat Statistik.

Badan Pusat Statistik. (2019). Kemiskinan dan Ketimpangan. Retrieved May 20, 2019, from https://www.bps.go.id/subject/23/kemiskinan-danketimpangan.html

Badan Pusat Statistik Provinsi Jawa Barat. (2017). Keadaan Angkatan Kerja di Provinsi Jawa Barat, Agustus 2017. (Bidang Statistik Sosial, Ed.). Bandung: Badan Pusat Statistik Provinsi Jawa Barat.

Badan Pusat Statistik Provinsi Jawa Barat. (2018a). Berita Resmi Statistik (BRS) Tingkat Kemiskinan dan Ketimpangan di Jawa Barat Maret 2018. Bandung. Retrieved from https://jabar.bps.go.id/pressrelease/2018/07/16/313/tingkat- 
kemiskinan-jawa-barat-maret-2018-sebesar-7-45-persen.html

Badan Pusat Statistik Provinsi Jawa Barat. (2018b). Keadaan Angkatan Kerja di Provinsi Jawa Barat, Agustus 2018. (Bidang Statistik Sosial, Ed.). Bandung: Badan Pusat Statistik Provinsi Jawa Barat.

Badan Pusat Statistik Provinsi Jawa Barat. (2018c). Kemiskinan Kabupaten/kota di Jawa Barat 2013-2018. (Bidang Statistik Sosial, Ed.). Bandung: Badan Pusat Statistik Provinsi Jawa Barat.

Badan Pusat Statistik Provinsi Jawa Barat. (2018d). Laporan Eksekutif Keadaan Angkatan Kerja Provinsi Jawa Barat Agustus 2018. (Bidang Statistik Sosial, Ed.). Bandung: Badan Pusat Statistik Provinsi Jawa Barat.

Baltagi, B. H. (2005). Econometric Analysis of Panel Data (Third Edition). England: John Wiley \& Sons, Ltd.

Fahar, F. (2015). Kemiskinan dan Ketenagakerjaan di Kepulauan Riau 2014: Permasalahan dan Implikasi Kebijakan. Jurnal Ekonomi Keuangan, 1-11. Retrieved from https://www.researchgate.net/publication/ 272052526_KEMISKINAN_DAN_KETENAGAKERJAAN_DI_KEPULA UAN_RIAU_2014_PERMASALAHAN_DAN_IMPLIKASI_KEBIJAKAN

Febriani, A. R. (2018). Analisis Pengaruh Tingkat Pengangguran, Rata-Rata Lama Sekolah, dan Pertumbuhan Sektor Industri Terhadap Kemiskinan di Provinsi Jawa Tengah Periode 2011-2015. Universitas Pembangunan Nasional "Veteran" Yogyakarta. Retrieved from http://eprints.upnyk.ac.id/15468/

Mahsunah, D. (2013). Analisis Pengaruh Jumlah Penduduk, Pendidikan dan Pengangguran terhadap Kemiskinan di Jawa Timur. Jurnal Pendidikan Ekonomi (JUPE), 1(3), 1-17. Retrieved from https://jurnalmahasiswa.unesa.ac.id/index.php/jupe/article/view/3645

Pemerintah Kabupaten Purwakarta. (2019). Rencana Pembangunan Jangka Menengah Daerah (RPJMD) Kabupaten Purwakarta Tahun 2018-2023. Purwakarta: Pemerintah Kabupaten Purwakarta.

Sudiana, I. W., \& Sudiana, I. K. (2015). Pengaruh PDRB, Pendidikan, dan Struktur Tenaga Kerja terhadap Kemiskinan di Provinsi Bali. E-Jurnal Ekonomi Pembangunan Universitas Udayana, 4(6), 608-620. Retrieved from https://ojs.unud.ac.id/index.php/eep/article/view/12061 